\title{
Potentials of Global Networking in SMS Technology: An Example of Nigerian Users
}

\author{
Tanimu Ahmed Jibril, Universiti Putra, Malaysia \\ Tan Bee Hoon, Universiti Putra, Malaysia \\ Shamsuddeen Mohammed, Ahmadu Bello University, Nigeria
}

\begin{abstract}
In the last two decades, Short Messaging Service (SMS) has witnessed a remarkable growth and acceptance worldwide. Among other Computer-Mediated Communication (CMC) avenues, it is regarded as one of the fastest in increase probably for being so instant and private. It is being estimated recently that short messages are being sent in trillions globally. In the Nigerian framework, the technology has been generating momentumas a phenomenon to be reckoned with socially and politically. The younger generation, above all, use the machinery to bring about social change, fight corruption, and actively monitor and participate in the local politics. This critique reviews related literature on the global nature of SMS and the inference of its use in a local milieu.Findings revealed that SMS has a variety of positive impacts on the lives of ordinary Nigerians. At the same time, results of some studies conducted on students at different levels of education raises some alarm over the growing influence of SMS language shortcuts on students' formal scripts. Socially, the literature has reiterated the increasing concern over the culture of 'sexting' and how capable it is in promoting social vices and incongruity among the Nigerian populace.
\end{abstract}

Keywords: GSM technology, Nigeria, short messaging service, SMS technology, CMC 


\section{Introduction}

The technology of SMS began as a tool for system up-keeping and customer notices in 1991 in Finland, and was later-on publicized sometime in the year 1994 (Pitfield, 2004; Taiwo, 2010; Kang \&Maity, 2012). Afterwards, SMS was picked up by the zealous youth in the West and was subsequently made to become an integral "part of mobile communication even in the era of the smartphone" (Taylor \& Vincent, 2005; Ling, 2005, in Kang \&Maity, 2012, p. 2). The three main categories of text-messaging or texting language (TL) include micro blogging, Instant Messaging (IM), and SMS (Tomita, 2009). As a rapid communication outlet, SMS is assessed as "a phenomenon that has grown and spread around the globe at an amazing speed" (Sulaiman\&Zolait, 2012, p. 44). It is considered to be the most popular tool of communication with an approximate 2.4 billion users worldwide (Grinter\& Eldridge, 2003; Short Message Service, 2008). It is so adopted due to its instantaneous nature, location independence, and privacy (Reid \& Reid, 2005, in Taiwo, 2010). In addition to these, it was projected that in the year 2011 alone, eight trillion text messages would be sent worldwide (Global Mobile Statistics, 2011, in Tossell, Kortum, Shepard, Barg-Walkow, \&Rahmati, 2012).

In 2001, Global System for Mobile Communication (GSM) was introduced into the Nigerian telecommunications sphere. Today, with an approximate 60 million mobile phone users, text messaging has become a driving force in building social relationships, monitoring political issues and fighting injustice in the Nigerian society. Out rightly, this growing trend is being championed by the younger generations in the country to the extent that they have been labelled as "the thumb tribe" for being skilled in manipulating phone and computer keyboards with their fingers, mainly the thumb (Taiwo, 2010, p. 1). Nigerians, generally, have been described as "compulsive text senders" by Andrew Walker, a BBC Correspondent in Nigeria, in his report of October 10, 2008, on BBC News. Besides, it is as well believed that "the Nigerians using SMS/TM appear to outnumber Nigerians writing formal books and periodicals....." (Faleke\& Ibrahim, 2011, p. 52). In spite of the above, Taiwo (2010) confirms that "scholarly publications on the culture of the use of text messaging in Nigeria are still few and far between" (p. 6). Nevertheless, a handful number of academic investigations have been taken up to study various aspects of SMS language in the Nigerian context (notably Awonusi, 2004; Ofulue, 2004; Obadare, 2006; Chiluwa, 2007 \& 2008; Alabi, 2008; Taiwo, 2008 \&2010; Faleke\& Ibrahim, 2011; Olofinniyi, Fashiku, Fashiku, \&Owombo, 2012; Njemanze, 2012). 


\section{Defining Short Messaging Service}

As a direct medium of communication that connects individuals today, SMS "is now a phenomenon that has grown and spread around the globe at an amazing speed". It is postulated that SMS is used widely not necessarily within the communication dichotomy, rather for other business purposes, i.e. marketing escapades, for its stumpy cost. (Sulaiman\&Zolait, 2012, pp. 44-45). The technology of SMS is simply defined as "a communications protocol used to deliver short text messages, up to 160 characters, via Global Systems for Mobile Communication (GSM) enabled mobile phones" (Tomita, 2009, p. 186). The Encyclopcedia Britannica (2013) defines text messaging as an "act of sending short messages with cell phones using the Short Messaging Service (SMS), which has a limit of 160 characters per message". It further explains that "because typing text into a telephone keypad was cumbersome and the number of characters in a text message was limited, a form of shorthand evolved, especially among young people". Moreover, the shortcuts nature of the SMS language is interpreted as a sort of "abbreviations, shortened words or codes used to communicate short messages with other cellular phone users" (Schaller, 2007, in Rankin, 2010, p. 8).

Textese as an electronic or CMC medium has been receiving tremendous attention recently. Three main categories of text-messaging or texting language include micro blogging, IM, and SMS. All these forms of communication media share many of the same features and can be classified as a variety of text-messaging or texting language (Tomita, 2009). Among the three forms of text-messaging stated above, SMS is considered to be the most popular tool of communication with an approximate 2.4 billion users worldwide. It is estimated that $90 \%$ of teenagers exchange SMS with friends with an average length of 70 characters per message (Grinter\& Eldridge, 2003; Short Message Service, 2008).

Scholars believe that the fast growing dissemination of information through electronic communication gadgets has automatically brought into existence new forms of English written texts (see for example, Crystal, 2001; Veronis\& de Neef, 2006). These written texts that come in forms of electronic messages or SMS language are highly categorized by enormous and methodical deviations from the writing standard, as well as by nonconventional application of alphabetical codes (Kobus, Yvon, \&Damnati, 2008). They are also asynchronous and are limited by a procedure that permits an utmost usage of 160 
characters for each message. It was such a constraint on the number of lettering allowed that gave rise to the common use of the abbreviated forms of linguistic codes being referred to as 'textese'. More or less as the language associated with IM and Chatting, textese are characterized with "abbreviation, logographic spelling and rebus forms of writing" (Warschauer, Black, \& Chou, 2010, p. 494).

Texting Language (TL) as such represents an overall growth of the written colloquial English versus formal or academic English. Such abbreviations enable a lot of people on the precincts of power to communicate in such a way that better expresses their sense of individuality and society (Warschauer et al., 2010). Since its arrival in December, 1992, and making it public in 1994, SMS technology has become one of the most widely patronized modes of communication. It is so adopted due to its instantaneous nature, location independence, and privacy (Reid \& Reid, 2005, in Taiwo, 2010).

Many scholarly studies have been carried out on the SMS language for the past 20 years (Choudhury, Saraf, Jain, Mukherjee, Sarkar, \&Basu, 2007). Orthographic and syntactic structures applied in TL have also been investigated for other languages, apart from English, such as Arabic (Palfreyman\& Khalil, 2003, in Choudhury et al., 2007) and Japanese (see Nishimura, 2003). A number of similar investigations on linguistic rudiments of SMS in various languages were also conducted. It includes French texting language (notably Anis, 2001; Fairon, Roechaut, Cougnon, \& Beaufort, 2006, etc), German texting language (Doring, 2002, in Ling \& Baron, 2007), Swedish texting language (afSegerstad, 2002), Norwegian texting language (Ling, 2005), and a study on British English textese (Thurlow, 2003).

\section{Short Messaging Service as a Global Approach}

At the initial stage, SMS was engineered for the purpose of "system maintenance or customer notifications". Then, mobile operators did not foresee any prospects in promoting SMS to non-business consumers (Kang \&Maity, 2012, p. 3). Notwithstanding its technical inadequacies, "SMS was unexpectedly picked up by the youth in the developed world and later became an essential part of mobile communication even in the era of the smartphone" (Taylor \& Vincent, 2005; Ling, 2005, in Kang \&Maity, 2012, p. 2). Additionally, SMS as a rapid communication channel is seen as "a phenomenon that has grown and spread around the globe at an amazing speed" (Sulaiman\&Zolait, 2012, p. 44). Likewise, it is one of the most 
employed methods of communication. It is available on almost all kinds of mobile phones with no considerations to where these phones were manufactured or the network system they customize.

The SMS technology is so dependable that even in rural areas with scanty coverage, SMS messages could easily be stocked up within the server and could be accessed the moment signals were restored (Fitzerald, Spriggs, \&Steinfield, 2010, in Kang \&Maity, 2012). Moreover, degrees of SMS adoption vary related to developed and the developing countries. For instance, prior to the emergence of SMS in advanced nations, people were already used to telegraphs, e-mails and pagers. On the other hand, in most of developing countries mobile phone users find SMS as their first text-based e-communication gadget. As the use of SMS becomes more or less prevalent in countries such South Africa and the Philippines, the situation in East Africa and South Asia indicates a very slow pattern of adoption of SMS, particularly, among rural and poor centre of population (Rheingold, 2002; Fremfong, Essegbey, \&Tetteh, 2007; LIRNEasia, 2008; Rashid \& Elder, 2009; Hellstrom, 2010; GSMA mWomen, 2012, in Kang \&Maity, 2012).

In the present day, SMS language usage has become a global tendency. The number of mobile phone owners is increasing worldwide. Nowadays, the culture of texting is very overwhelming not only in teen text senders, rather in a wider scope of the usage that include general users. Recently, a study indicates that "the median US teen text users send out 60 texts a day while their voice call frequency is on the decline" (Pew Internet \& American Life, 2012, in Kang \&Maity, 2012, p. 3). An additional survey conducted in 2008 in South Asian countries reported that almost $30 \%$ of the Bottom of the Pyramid (BOP) mobile phone owners in Bangladesh and India had either sent or received a text message (LIRNEasia, 2008). In the same way, an approximate $37 \%$ of the same BOP women in another four developing nations had used SMS without putting their educational status into account (GSMA mWomen, 2012). In an article entitled 'Can Apple win over China?' in Fortune magazine (October, 2012 edition), Bill Powell estimates mobile phones users in mainland China when he states that “......China Mobile, the world's largest wireless operator, with 655 million users on its network" (pp. 41-46). 


\section{Conversational Nature of Short Messages Language}

Presently, one of the issues generating a big deal of debates among scholars is the possible effects the SMS language may have on the formal writing ability of the younger generation (Taiwo, 2010). In a study carried out to examine text messaging and the implications for its use in education, Tomita (2009) claims that SMS psyches students up to write more and more. At the same time, it allows educators to communicate properly. In support of his assertion, he indicates that some studies have already shown that most of students engaged in text messaging are still able to differentiate between the standard and the non-standard form of writing. The study concludes that text-messaging tools enhance a workable means of teaching students 21 st century skills to enable them communicate efficiently and work as a team (Tomita, 2009). Contrary to this notion, some are of the opinion that SMS inculcate poor writing habits in students. For instance, in a New York Times article, an educator put across concern over the use of abbreviations such as " $u$, r, ur, b4, wuz, cuz, 2" that began to appear lately in students writing. The article further states that, such abbreviations are, undoubtedly, element of an "online lingua franca: English adapted for the spitfire conversational style of internet instant messaging" (Lee, 2002, 8th paragraph). On the other hand, the media as well has tagged this "online lingua franca" as "the bastardization of language" (O'Connor, 2005, in Tagliamonte\& Denis, 2008, p. 4), "the linguistic ruin" of the modern time (Axtman, 2002, in Tagliamonte\& Denis, 2008, p. 4), and the "penman for illiterates" (Sutherland, 2002, in Taiwo, 2010, p. 4). In a huge critique of the texting culture particularly among the youth, Sutherland (2002) further declares that:

As a dialect, text ('textese'?) is thin and - compared, say, with Californian personalized license plates - unimaginative. It is bleak, bald sad shorthand. Drab shrinktalk.... The dialect has a few hieroglyphs (codes comprehensible only to initiates) and a range of face symbols... Linguistically, it's all pig's ear....it masks dyslexia, poor spelling and mental laziness. Texting is penmanship for illiterates (6th-7th paragraph).

A qualitative inquiry into the impacts of the SMS language abbreviations on the formal writing skills of developmental students has been carried out by Rankin (2010). The study sampled 25 respondents from the Summer Developmental Programme of Jackson State University in 2009. Major findings of the investigation show that participants' usage of SMS 
shortcuts "have become common in their academic writing assignments". It also indicates that "text messaging language shortcuts have hurt students' spelling skills in general" (p. 58). On the other hand, findings from observations and artefacts (previous assignments sheets) in the same study reveal that other errors have also been found alongside SMS shortcuts in students' formal writings.

In an attempt to examine the linguistic forms and communicative functions of youth's text message patronage, Thurlow (2003) finds out that the major linguistic changes that youth brought about (i.e. abbreviations, contractions, misspellings and non-conventional spellings, acronyms, etc) were "serving the sociolinguistic 'maxims' of (a) brevity and speed, (b) paralinguistic restitution and (c) phonological approximation". Language experts believe that these new trends were linguistically "unremarkable" and also "would not be out of place on a scribbled note left on the fridge door" (section 4). In the same vein, Thurlow (2003) emphasizes on a subject matter that currently features most in academic researches and commentaries on the possible linguistic change that may evolve with the expansion of the Information and Communication Technology (ICT) machineries (such as e-mail, IM, chat, and SMS). Most of them believe that these instruments did not, and do not, actually engineer any changes in language forms, rather they intensify trends already in existence. Moreover, according to the experts, studies always show that degrees of informality and the use of nonstandard differ depending on the context and purpose. Interestingly enough, Crystal (2008) claims that "people have been initializing common phrases for ages. IOU is known from 1618. There is no difference, apart from the medium of communication, between a modern kid's loland an earlier generation's Swalk" (14th paragraph).

In an entirely different hypothesis, it is believed that the components of SMS language represent a "new linguistic style" that is, in the long run, gaining ground within the language to establish that the language has got a new orthography. This takes place, according to the supposition, "as the world is witnessing new developments and cultures, new words, coinages and new styles of expression evolve as part of those development processes" (Chiluwa, 2007, p. 45) as cited in Faleke and Ibrahim (2011).

Usually, academic research on forms of CMC have a tendency to fall into two categories: "studies celebrating the unique nature of online registers; and studies disavowing any 
significant difference between on- and offline communication, save for the medium" (Warschauer et al., 2010, p. 492).

\section{Global System of Mobile in Nigeria}

In January, 2001, GSM was introduced into Nigeria to mark the beginning of what has been termed as GSM Revolution in the country. The machinery of GSM composes of a TDMA based "digital cellular phone technology" that was initiated in Europe and subsequently goes internationally. The system is believed to delineate the "entire cellular system, not just the TDMA air interface" (The Free Dictionary Online, 2012). Additionally, GSM apparatus has been characterized as a "time-division multiple accesses" based equipment. The tool "operates on the 900-megahertz and 1.8-gigahertz bands in Europe, where it is the predominant cellular system and on the 1.9-gigahertz band in the United States" (McGrawHill Dictionary of Scientific \& Technical Terms, 2003).

By the year 2008 various GSM services providers had approximately 59 million active subscribers in Nigeria and "a teledensity" (a quantity of telephone lines in relation to residents) of 42\%" (Taiwo, 2010, p. 2). It has been reported that preceding the year 2001 "the number of connected phone lines in the country were a mere 450,000 for an estimated population of 120 million at the time" (Tella, Adetoro, \&Adekunle, 2009, p. 55) The introduction of the GSM system of communication into the country has been described as a kind of "a great relief" to the citizens "after years of decay" in the Nigerian telecommunication industry. The new method has been characterized as being "handy, movable and mobile" that provides users with their diverse wants (Faleke\& Ibrahim, 2011, p. $52)$.

In the year 1999, Nigeria had a record of being the world's third lowest in terms of teledensity, after Mongolia and Afghanistan, with the average of 0.73\% (Okereocha, 2008, in Olofinniyi et al., 2012). According to some experts, some Nigerians tend to believe that GSM Revolution is almost the second independence for the country as it brought about more than enough opportunities and stress free ways of communication. In addition to this, the Nigerian market - in terms of mobile phones purchase and usage - is believed to be growing at an astronomical tempo. As of 2006, statistics indicated that the country was accounting for almost $14 \%$ of total mobile phone users in Africa (Tella et al., 2009). 
On the other hand, employment and jobs creation are among the benefits that came along with the GSM introduction in the country. The sector has become the highest absorber of both skilled and unskilled employees recently. It provides direct employment opportunities to young graduates in various GSM industries that enhances them a better living. Away from each other, indirect opportunities were also created where many people were enabled to become self-reliant by means of business of commercial phone calls and sells of GSM recharge cards to phone users. Society wise, Nigerians benefits from a number of Corporate Social Responsibility packages of GSM service providers and telecommunication companies. Programmes such as providing educational facilities, Acquired Immune Deficiency Syndrome (AIDS) awareness campaign and amelioration, provision of up-to-date Information and Communication Technology (ICT) laboratories to academic institutions, awarding scholarship to bright students and other charity activities are all part of the Corporate Social Responsibility packages (Omeruo, 2007).

A study was conducted by Olatokun and Bodunwa (2006) on GSM usage at the University of Ibadan, Nigeria, where $278(68.2 \%)$ of the respondents agreed that mobile phones are far better than landline telephony system. The outcome of the survey also shows that mobile phones are proper time managers, potable, convenient and user friendly. Ndukwe (2003) is of the opinion that with the advent of mobile phone usage, business transactions have become much more productive, cheaper and safer. He adds that mobile phone empowers all social classes in the society. According to Aihe (2008), Global System of Mobile Communication (GSM) operation embodies the potency and beauty of industrial management in Nigeria. Collate acknowledgements in a separate section at the end of the article before the references. List here those individuals who provided help during the research (e.g., providing language help, writing assistance or proof reading the article, etc.).

\section{Texting and the Nigerian Society}

With the so called GSM Revolution in Nigeria ever since its introduction into the system, mobile phones have become a widely used means of communication among the general populace. It offers both old and young avenues to interact by the use of voice and SMS. This phenomenon serves as a sort of confirmation to Fischer's (1988) characterization of cell phones and SMS as "technologies of sociability". The younger generations in the country, in 
particular, could simply be compared with their counterparts all over the world for being well skilled in terms of phone and computer keys manipulations. While the majority of older people use mobile phones for mostly voice communication purposes, the teenagers and young adults have customized the use of SMS for socializing and keeping relationships (Taiwo, 2010, p. 1).

Scholarly research works on the culture of text messaging in the Nigerian context are still very few, and Awonusi (2004) as cited in Taiwo (2010) happens to be among the earliest investigations conducted in that respect. In the study, the researcher discusses how Nigerians utilize SMS despite space constraint by way of innovative writing skills. Grammatical and orthographical peculiarities associated with the Nigerian brand of SMS were also examined. Awonusi (2004) was quoted in Taiwo (2010) explaining that:

Apart from the peculiar phonetic representations and orthographic representations, Nigerian text messages have both orthographic and grammatical peculiarities, such as nonuse of internal punctuation (comma, colon, semi-colon), the admixture of upper and lower case characters, shortening of auxiliary and modal verbs as is often done in informal writing, for example: I'll for I will, he'd for he would, and the deletion of nouns, and groups functioning as nouns, so forth. In addition, there were features of what he describes as 'text multilingualism' (code-switching and code-mixing) (p. 6).

Likewise, an additional study carried out by Ofulue (2004) as cited in Taiwo (2010) as well focuses on the use of local languages for texting. The investigation concludes that such a practice gives some sort of sociolinguistic recognition to the indigenous languages within the sphere of SMS use.

Furthermore, an inquiry was conducted in order to establish whether there is any parallel between the access to cell phones and the academic performance of students at High school level. Olofinniyi et al. (2012) sampled students from approximate 10 senior secondary schools in Osun State, Nigeria, for the purpose of the examination. Results of the study showed that there were no substantial connection between students' access to mobile phones and students' 
academic performance. Therefore, cell phones do not contribute positively, in any way, to the students' performance in the State; rather, it has done some damages instead.

In line with the assertion above regarding the tendency low performance and poor writing habits infused in students by way of texting, Faleke and Ibrahim (2011) carried out an investigation on GSM text messages as impediment to English orthography in the 21st Century. The study was carried out in order to see how different styles of writing, through SMS devices, adopted by many Nigerians have been transferred into the standard writing in essay questions. The samples used were some selected West African School Certificate Examinations (WASCE) essays of students ranging from 2006 to 2009. The findings show remarkable occurrences of SMS language markers at morphophonemic, orthographic as well as expression manner which, eventually, would affect their performance in examinations negatively. The investigation identified some sorts of punctuation errors, inappropriate use of apostrophe, poor capitalization, wrong compounding, poor paragraphing, and apparent spelling errors (i.e. cant' instead of can't; johnson and faTher instead of Johnson and father;some thing instead of something; hear, betwn, ples, matreat and stude instead of here, between, maltreat, and study,etc). The researchers assume that students nowadays lack much of reading culture which could likely upgrade both their reading and writing competences. The study concludes that these SMS features in formal essay writing in examinations, "consciously or otherwise, may eventually adulterate the standard of English usage in Nigeria" (Faleke and Ibrahim, 2011, p. 50).

Subsequent to Olofinniyi et al.'s (2012) and Faleke and Ibrahim's (2011) conclusions, Njemanze (2012) maintains that with the so called SMS form of communication that has in the long run become a global happening; students in Nigeria have been mechanically influenced in their formal writings. She cautions students at various levels of education not be fancied by the "social relevance of text messaging" for the obvious truth that "bastardization of a language cannot enhance its development" (p. 22). This notion of 'bastardization' - with reference to text messaging - presupposed by Njemanze (2012) has earlier been subscribed to by a number of scholars. According to them, SMS represents "the bastardization of language" (O'Connor, 2005, in Tagliamonte\& Denis, 2008, p. 4) and "the linguistic ruin" (Axtman, 2002, in Tagliamonte\& Denis, 2008, p. 4) of the recent era. Besides, application of SMS in a 
formal writing has been described as "method in madness" (Alabi, 2008, in Faleke\& Ibrahim, 2011, p. 51).

So far, most parts of the arguments above have been on the impacts of SMS on students' performance and formal writings. Socially, SMS is gaining momentum as an alternative medium through which ordinary people express their opinions without being monitored. In an article entitled 'The thumb tribe': Creativity and Social Change through SMS in Nigeria, Taiwo (2010) discusses how "the popularity of SMS has created a forum for Nigerians to articulate themselves in fighting all forms of injustices, monitoring political activities and building social relationships" (p. 1). The researcher investigated a corpus of 4876 personal SMSes collected between 2006 and 2008 in the south western part of Nigeria, and the age of the participants ranged between 16 and 30 years old. It has been observed that among the wider Nigerian community, younger generations constitute the majority of SMS senders. Therefore, the researcher targeted such a population "because of the potentiality of generating the creative text messages employing innovative English usage" (p. 7). Such a utility of the technology for variety of purposes triggered a kind of creativity and fashion as much as the composition of text messages is concerned. For instance, in a reference to the use of emoticons in SMS dialogue, Taiwo (2010) further categorizes the levels of design by means of using pictures and icons into "artistic" and "poetic". He explains that, "artistic creativity" is all about how to put together the ASCII symbols in order to come up with diverse pictographic reflections, while "poetic creativity" is about the choice of suitable words that go with the images formulated (p. 15). After all, application of such non-verbal codes replaces the absence of most of the face-to-face attributes that are already missing in electronic forms of communication. In other words, they are more or less substitute for the "facial expressions and prosodic features" (Amaghlobeli, 2012, p. 348; Rezabeck\&Cochenour, 1998).

The notion of creativity and fashion in Nigerian SMS composition raised above by Taiwo (2010) is represented in how Nigerians play with orthography and come up with an artificial "state of well-being in the face of gloomy socio-economic a political situation in the country". It is also a technique through which Nigerians "draw powerful positive symbols out of ideas that will naturally evoke seemingly negative ones". Therefore, the so-called "creative texts" give room for "looking beyond the literal concept representation" (pp. 7-8). In an examination 
of what could be considered as a manner of creativity in the Nigerian text messaging, Taiwo (2010) sampled a number of examples which includes the following:

M1: You are such an IDIOT. It simply means that $u$ are

I- Intelligent

D- Decent

I-Impressive

O-Optimistic and

T-Tolerated

Are u smiling now u IDIOT. Make sure u call111ll me now IDIOT....lol... (p. 8).

M2: I want 2 give u POISON, ready to take it; P- Progress, O- Overwhelming, IIndependent, S- Success, O- Opportunities, N- New dawn. Swallow d poison! (p. 8).

M6: God will take u FIRST 2 d ZENITH of joy, GUARANTEE ur ACCESS 2 success, Put DIAMOND in ur SKYE \& give u INTERCONTINENTAL testimonies (p. 9).

M7: Dis month, God will TANTALIZE u with his grace. Angels will be on guard to give U a SWEET SENSATION favor. God will make u MR BIGGS among ur equals. Have a TATEE month (p. 9).

M12: d last time u dragged me 2 court for owing u some love, d justice asked me how much love I owe u, I told him it was uncountable \&dat I won't be able 2 Finish the payment, even til eternity. Den, d judge adjourned d case till after our wedding day! If it is raining, I'll love $u$, if it is sunny I'llcherish $u$, if it is dark I'll value $u$, if it is hot I'll admire u, \& even in a cold weather I'll handle u like a treasure (p. 11).

M13: Court Order

$\mathrm{U}$ are accused of crawling into my life \& hijacking my heart with ur sweet smiles \& attitude, How can u plead innocence.

$\mathrm{U}$ are hereby sentenced 2 be my darling 4 ever (p. 11).

M16: If I had letters "HRT", I can add "EA" to get a "HEART" or a "U" and get "HURT". But I'd rather choose "U" and get "HURT" than have a "HEART" without "U" (p. 11).

M22: $><(((:>$ I send dis fish as a sign of friendship Plztke care of it \& keep it in mobile $\&$ daily put ur mobile in water so tat fish wont DIE (p. 14). 
At the same time when the mechanisms of SMS are being applied for the purpose of fighting corruption, injustice, and building healthy social rapport among Nigerians, there are other ugly faces of the technology at work. An instance of such negative parts of SMS is its propensity to facilitate and promote the sending of sexualized and shameless messages for the most part among youths. The possibility of proving such a theory becomes very high as the possession of smartphones becomes very common nowadays. In an attempt to examine the hypothesis, Dauda (2012) conducted a study on sexting trends among selected Nigerian undergraduate students. Findings of the investigation indicated that $31 \%$ of the respondents admitted that they send sexy messages or naked pictures on their mobile phones; while $69 \%$ said they do not. But when asked if their friends send or receive sexy messages or naked pictures on their phones, majority of the respondents, that is $52 \%$, said they do, while $44.4 \%$ said they do not, and 3.5\% said they do not know. Similarly, majority of the respondents $78.9 \%$ express their concern about sending sexy or nude text messages on mobile phones by describing it as bad and unhealthy act as they believe that it will cause more harm than good to the norms and values of the society in general. The study concluded that sexual gratification, emotional stability and entertainment are the main factors motivating students to send sexy text messages, describing sexting as a social problem capable of inducing immorality among youths in the society.

Corresponding to Dauda's (2012) inquiry in respect of sending sexy messages using mobile phones, Rishante and Gambo (2012) carried out an assessment on the responses of the cell phone users to violent text messages in Nigeria. The findings indicated that majority of the respondents $74 \%$ expressed how surprising, shocking and disgusting it always sounds whenever they receive vulgar or abusive text messages; while $41 \%$ of the respondents voiced out their readiness to take revenge for receiving such messages if at all they can be able to identify its sender.

\section{Conclusion}

To sum it up, this appraisal has assessed the technology of SMS technology from two angles. Firstly, it has reviewed the universal inclination of the phenomenon; and secondly, discussed the adoption as well as use of the SMS within the Nigerian parameter. Related literature reviewed so far has shown that among other CMC forms of communication, SMS is going faster in terms of spread, and is being adopted more for instantaneity, independence, and 
privacy. In addition, text messages are being sent trillions in worldwide (Sulaiman\&Zolait, 2012; Reid \& Reid, 2005; Global Mobile Statistics, 2011). The literature has also pointed out that the technology is so reliable that even in rural areas with scanty coverage, SMS messages could easily be stocked up within the server and could be accessed the moment signals were restored (Fitzerald, Spriggs, \&Steinfield, 2010).

The review likewise reveals that apart from its adoption and usage in the West - where it originated from, and unlike other CMC means of communication - SMS is being rapidly adopted and used in other parts of the world. Examples were cited of its adoption in East Africa, South Africa, The Philippines, and the South Asia by average people from rural areas. In order words, sending or receiving an SMS does not necessarily require attaining a high educational status. It has been reported that $30 \%$ of the Bottom of the Pyramid (BOP) mobile phone owners in Bangladesh and India had either sent or received a text message (LIRNEasia, 2008; GSMA mWomen, 2012; Hellstrom, 2010).

On the other hand, the review discloses that GSM introduction into Nigeria in 2001 has significantly re-energized a then dying-off communications sector. With such a development, mobile phone communication system has become the most preferred alternative in the country as the statistics shows that there were virtually 60 million active subscribers by the year 2008 (Taiwo, 2010). SMS or texting is a very essential feature of GSM as a new medium of mass communication. With mobile phones at hand, the culture of texting was becoming a habit among Nigerians, predominantly, the younger ones. It is believed that it enables users to save time, money and effort in sending or receiving information and messages from friends, relatives, colleagues and business associates. It is being celebrated as a substitute medium where individuals feel free to communicate and express their views with fewer restrictions socially, politically and so on. At the same time, some scholars have the reservation that this growing trend of texting is becoming a hindrance to students' good mastery of the conventional written and spoken English. Some research works conducted on the effects of SMS on students in Nigeria have already established instances of some occurrences of SMS language markers in the students' formal orthographies and expression manners.

The critique, nevertheless, concludes that texting in the Nigerian society and beyond is being associated with some negative acts that can facilitate social vices and disharmony among 
people. According to the review, these doings include sending fraudulent, sexy and nude, and violent text messages to people in the society. It has been observed that "the interactive and unhindered nature of the mobile phone, a form of new media, is providing youth with a lethal device to alter the value system of sexual relations, thereby threatening the existing core values of the community" (Dauda, 2012, p. 423). Therefore, it is the responsibility of the government, parents and GSM service providers to reorient and monitor the pattern of texting among subscribers in Nigeria. This will ensure effective control of the problems associated with the culture of text messaging in the country. 


\section{References}

afSegerstad, Y.H.(2002). Use and adaptation of written language to the conditions of computer-mediated communication. (Unpublished $\mathrm{PhD}$ thesis). Department of Linguistics, Göteborg University, Sweden.

Aihe, O. (2008, Dec. 20). Saving GSM companies from themselves.Vanguard. Retrieved from http://www.vanguardngr.com

Alabi, V. A. (2008). Problems of an emergent written language of the Global System for Mobile Communication (GSM) in Nigeria.Proceedings of the 22nd Annual Conference of the Nigeria English Studies Association (NESA), 194-203.

Amaghlobeli, N. (2012). Linguistic features of typographic emoticons in SMS discourse. Theory and Practice in Language Studies, 2(2), 348-354. Doi: 10.4304/tpls.2.2. 348354.

Anis, J. (2001).Parlez-voustexto ? Guide des nouveaux langages du réseau. Éditions du Cherche Midi.

Awonusi, S. (2004). Little Englishes and the law of energetic: A sociolinguistics study of SMS text messages as register and discourse in Nigerian English. In A. Segun\& E. A. Babalola (Eds.), The Domestication of English in Nigeria. Lagos: University of Lagos Press.

Axtman, K. (2002). R u online?: The evolving lexicon of wired teens. The Christian Science Mirror. Retrieved from http://www.csmonitor.com/2002/1212/p01s01-ussc.html

Boardman, M. (2005).The language of websites. London \& New York: Routledge Taylor \& Francis Group.

Chiluwa, I. (2007). The 'Nigerianess' of SMS text message in English.Journal of the Nigerian English Studies Association, 2(1), 95 - 109.

Chiluwa, I. (2008). SMS text-messaging and the Nigerian Christian context: Constructing values and sentiments. The International Journal of Language, Society and Culture, 24, 11 - 20. Retrieved from http://www.educ.utas.edu.au/users/tle/JOURNAL/issues 12008/24-2.pdf

Choudhury, M., Saraf, R., Jain, V., Mukherjee, A., Sarkar, S., Basu, A. (2007). Investigation and modelling of the structure of texting language. IJDAR 10:157 - 174. DOI 10.1007/s10032-007-0054-0.

Crystal, D. (2001). Language and the Internet. (2nd ed.). Cambridge: CUP. 
Crystal, D. (2008, July 5). '2b or not 2b?'Guardian.Retrieved from http://www.guardian. co.uk/books/2008/jul/05/saturdayreviewsfeatres.guardianreview

Dauda, S. (2012). Sexting trends among selected Nigerian undergraduate students. In D. Wilson (Ed.), The media, terrorism and political communication in Nigeria. (pp. 410426). Nigeria: African Council for Communication Education, Nigeria Chapter.

December, J. (1997). Notes on defining of computer-mediated communication.ComputerMediated Communication Magazine [On-line], 4(1).Retrieved from http://www. december.com/cmc/mag/1997/jan/December.html

Doring, N. (2002). Kurzmwirdgesendet—abk"urzungen und akronyme in der SMSkommunikation. MutterspracheVierteljahresschriftf"ur deutsche Sprache 2.

Faleke, V. O., \& Ibrahim, S. S. (2011). GSM text messages: impediment to English orthography in the 21st century. Journal of the Nigeria English Studies Association (JNESA), $14(2), 50-60$.

Fairon, C., Klein, J. R., \&Paumier, S. (2006). Le langage SMS. UCL Presses Universitaires de Louvain.

Fischer, C. (1988). Gender and the residential telephone, 1890-1940: Technologies of sociability. Sociological Forum, 3(2), 211 - 233.

Fitzerald, R., Spriggs, J., \&Steinfield, C. (2010). Enhancing communications in developing Countries using SMS technology: The case of agricultural value chains in Cambodia. International Journal of Continuing Engineering Education and Life-Long Learning, 20(1), $72-83$.

Frempong, G., Essegbey, G., \&Tetteh, E. (2007). Survey on the use of mobile telephones for micro and small business development: The case of Ghana. Accra: CSIR-Science and Technology Policy Research (STEPRI).

Global Mobile Statistics (2011). Retrieved from http://mobithinking.com/mobile-marketingtools/latest-mobile-stats

Global System for Mobile Communication. (2012). In The Free Dictionary Online. Retrieved from http://encyclopedia2.thefreedictionary.com/Global+System+for+Mobile+Communicat ion

Grinter, R., \& Eldridge, M. (2003). Wan2tlk?: Everyday text messaging. Proceedings of ACM Conference on Human Factors in Computing System (CHI 2003), pp. 441-448.

Fort Lauderdale, Florida, USA, April, 2003. 
GSMA mWomen (2012). Striving and surviving: Exploring the lives of women at the base of the pyramid. GSMA mWomen Programme, London, UK.

Harley, D., Winn, S., Pemberton, S., \& Wilcox, P. (2007). Using texting to support students' transition to university. Innovations in Education and Teaching International, 44(3), 229-241. doi: 10.1080/14703290701486506.

Hellstrom, J. (2010). The innovative use of mobile applications in East Africa.Swedish International Development Cooperation Agency (SIDA), Stockholm, Sweden.

Kang, J., \&Maity, M. (2012). Texting among the bottom of the pyramid: Facilitators and barriers to SMS use among the low-income mobile users in Asia. LIRNEasia. International Development Research Centre, Canada, and UKaid, Department for International Development, UK.

Kobus, C., Yvon, F., \&Damnati, G. (2008). Normalizing SMS: are two metaphors better than one? Proceedings of the International Conference on Computational Linguistics (Cooling 2008), pp. 441-448. Manchester, August, 2008.

Lee, J. (2002, Sept. 19). 'I think, therefore IM'.New York Times. Retrieved from http://query.nytimes.com/gst/fullpage.html?res=9F06E5D71230F93AA2575AC0A964 9 C8B63

Lewis, C., \&Fabos, B. (2005).Instant messaging, literacies, and social identities.Reading Research Quarterly, 40(4), 470-501. Retrieved from http://www.reading.org/publications/journals/rrq/v40/i4/.

Ling, R. (2005). The socio-linguistics of SMS: An analysis of SMS use by a random sample of Norwegians. In Ling, R. \& Pedersen, P. (Eds.), Mobile communications: Renegotiation of the social sphere (pp. 335 - 349). London: Springer.

LIRNEasia (2008). Teleuse at the bottom of the pyramid data booklet: Findings from six country study in emerging Asia, LIRNEasia. Retrieved from http://lirneasia.net/wpcontent/uploads/2008/04/Teleuse-at-BOP-Data-Booklet-LIRNEasia.pdf

Global System for Mobile Communication. (2003). In McGraw-Hill Dictionary of Scientific \& Technical Terms. (6th ed.).The McGraw-Hill Companies, Inc.

Ndukwe, E. (2003, December 30). The role of telecommunication in national development. The Guardian, pp. 38.

Nishimura, Y. (2003). Linguistic innovations and interactional features of casual online communication in Japanese. Journal of Computer Mediated Communication, 9(1). 
Njemanze, Q. U. (2012). The 'SMS' style of communication: Implication on language usage among Nigerian university students. Journal of Communication, 3(1), 17-23.

Norris, A. R. (2012). Computer-mediated communication and globalization: Considering social, academic, and business factors. Student Pulse, 4(2), 1/1. Retrieved from http://www.studentpulse.com/articles/617/computer-mediated-communication-andglobalization-considering-social-academic-and-business-factors

Obadare, E. (2006). Playing politics with the mobile phones in Nigeria: Civil societies, big businesses and the state. Review of African Political Economy, 33(107), 93-111.

O’Connor, A. (2005). Instant messaging: Friend or foe of student writing? Retrieved from http://www.newhorizons.org/strategies/literacy/oconnor.htm

Ofulue, C. I. (2004). Interconnexity in other tongues: A sociolinguistic study of SMS texts in Yoruba.A Paper presented at the 18th Annual Conference of Linguistics Association of Nigeria, University of Port Harcourt, Nigeria.

Okereocha, C. (2008, March 22). Seven years of telecoms revolution. One revolution: A thousand gains. Tell Magazine, p. 28.

Olatokun, M. W., \&Bodunwa, I. O. (2006).GSM usage at the University of Ibadan.The Electronic Library, 24(4), 530 - 547.

Olofinniyi, O. E., Fashiku, C. O., Fashiku, B. C., \&Owombo, P. T. (2012). Access to GSM and students' performance in secondary school of Osun state, Nigeria. Online Journal of Social Sciences Research, 1(5), 160 - 165. ISSN 2277-0844. Retrieved from http://www.onlineresearchjournals.org/JSS

Omeruo, K. (2007). The impact of GSM mobile phone on Nigerians. Retrieved from http://www.kiwanja.net/database/article/article_nigeria_impact.pdf

Palfreyman, D., \& al Khalil, M. (2003). A funky language for teenzz to use: Representing Gulf Arabic in instant messaging.Journal of Computer Mediated Communication, 9(1).

Pew Research (2012, March 19). Teens, Smart phones \& texting.Pew Research Centre's Internet \& American Life Project, Washington, DC.

Pitfield, K. (2004). The social shaping of text messaging in North American youth culture. (Unpublished master's thesis). Department of Communication Studies, Concordia University Montreal, Quebec, Canada.

Powell, B. (2012, October 29). Can Apple win over China? Fortune, 15(Asia Pacific edition), $41-46$. 
Rankin, S. L. (2010). The impact of text messaging language shortcuts on developmental students' formal writing skills. (Unpublished doctoral thesis). Walden University, Minnesota, USA.

Rashid, A. T., \& Elder, L. (2009). Mobile phones and development: An analysis of IDRCsupported projects. Electronic Journal of Information Systems in Developing Countries, 36(2), $1-16$.

Reid, D. J., \& Reid, F. J. (2005). Textmates and text circles: Insight into the social ecology of SMS text messaging. In Lasen, A. \& Hamill, L.(Eds.), Mobile world, past, present and future (pp. 105 - 118). London: Springer.

Rezabek, L.L., \&Cochenour, J.J. (1998). Visual cues in computer-mediated communication: Supplementing text with emoticons.Journal of Visual Literacy, 18, 201-215.

Rheingold, H. (2002). Smart jobs.The next social revolution. Cambridge, MA: Perseus Books.

Rishante, J. S. \&Gambo, S. (2012). An assessment of the responses of cell phone users to violent text messages. In D. Wilson (Ed.), The media, terrorism and political communication in Nigeria (pp. 357-368). Nigeria: African Council for communication Education, Nigeria Chapter.

Schaller, R. C. (2007). “Litorality:” Text messaging as a hybrid written-spoken form of Communication in technological appropriation among young people. (Unpublished master's thesis). University of Wyoming.ProQuest. (UMI No. 1446914).

Short Message Service. (2008). Retrieved from http://en.wikipedia.org/wiki/Short_message _service

Short Messaging Service.(2013). In Encyclopcedia Britannica.Retrieved from http://www. britannica.com/EBchecked/topic/1571481/Short-Messaging-Service

Sutherland, J. (2002, November 11). 'Can u txt?' Guardian.Retrieved from http://www.guardian.co.uk/technology/2002/nov/11/mobilephones2

Sulaiman, A., \&Zolait, A. H. S. (2012). Adoption of short messaging service (SMS) in Malaysia. IGI Global. DOI: 10.4018/978-4666-1752-0.ch004

Tagliamonte, S., \& Denis, D.(2008). Linguistic ruin? LOL! Instant messaging and teen language. American Speech, 83(1), 3 - 34.

Taiwo, R. (2008). Interpersonal social responsibility in the context of SMS messaging in South-Western Nigeria. In T. Babawale, \& O. Ogen (Eds.), Culture and society in Nigeria: Popular culture, language and inter-group relations. Lagos: Centre for Black and African Arts and Civilization (CBAAC), 165-199. 
Taiwo, R. (2010). 'The thumb tribe': Creativity and social change through SMS in Nigeria. California Linguistic Notes, $X X X V(1)$.

Taylor, A. S., \& Vincent, J. (2005). An SMS history: in Hamill, L., \&Lasen, A. (Eds.), Mobile world: Past, present and future (Ch.4, pp. 75 -92). London: Springer.

Tella, A., Adetoro, N., \&Adekunle, P. A. (2009). A case study of the Global System of Mobile Communication (GSM) in Nigeria. UPGRADE: The European Journal for the Informatics Professional, X (2), 54 - 59.

Text messaging.(2013). In Encyclopcedia Britannica.Retrieved from http://www.britannica.com/EBchecked/topic/1099476/text-messaging

Information and Communication Technology. (2010). In The Free Online Dictionary of Computing. Retrieved from http://foldoc.org

Thurlow, C. (2003). Generation Txt? The sociolinguistics of young people's text-messaging. Discourse Analysis Online, 1(1). Retrieved from http://extra.shu.ac.uk/daol/articles/ v1/n1/a3/thurlow2002003.html

Thurlow, C., Lengel, L. B., \&Tomic, A. (2004). Computer-mediated communication: Social interaction and the Internet. Thousand Oaks, CA: Sage Publications.

Tomita, D. K. (2009).Text messaging and implications for its use in education. TCC 2009 Proceedings, $184-193$.

Tossell, C. C., Kortum, P., Shepard, C., Barg-Walkow, L. H., \&Rahmati, A. (2012). A longitudinal study of emoticon use in text messaging from smart phones. Computers in Human Behaviour, 28, 659 - 663.

Véronis, J., \& de Neef, É. G. (2006). Le traitement des nouvellesformes de communication écrite. In S. Gérard (ed.), Compréhensionautomatique des langueset interaction, (pp. 227-248). Paris: Hermès Science.

Walker, A. (Reporter). (2008, October 10), BBC news [Television Broadcast]. London: British Broadcasting Corporation (BBC).

Warschauer, M., Black, R. \& Chou, Y.-L. (2010). Online Englishes. In A. Kirkpatrick (ed.), The Routledge handbook of world Englishes (pp.490-501). London \& New York: Routledge Taylor \& Francis Group. 